\title{
窒化ケイ素の熱伝導率に及ぼす焼結体中の酸素の影響
}

\author{
林＼cjkstart裕之 ·平尾喜代司 $\cdot$ 北山幹人* $\cdot$ 山内幸彦・神崎修三 \\ 産業技術総合研究所シナシーマテリアル研究センター，463-8687 名古屋市守山区下志段味穴ヶ洞 2268-1, \\ 志段味ヒューマンサイエンスパーク先端技術連携リサーチセンター内 \\ *福岡工業大学機能材料工学科, 811-0295 福岡市東区和白東 3-3-1
}

\section{Effect of Oxygen Content on Thermal Conductivity of Sintered Silicon Nitride}

\author{
Hiroyuki HAYASHI, Kiyoshi HIRAO, Mikito KITAYAMA, ${ }^{*}$ Yukihiko YAMAUCHI and Shuzo KANZAKI \\ National Institute of Advanced Industrial Science and Technology (AIST), Synergy Materials Research Center, \\ 2268-1, Shimo-Shidami, Moriyama-ku, Nagoya-shi 463-8687 \\ *Fukuoka Institute of Technology, 3-3-1, Wajiro-Higashi, Higashi-ku, Fukuoka-shi 811-0295
}

\begin{abstract}
Silicon nitride powders with concurrent addition of $\mathrm{Yb}_{2} \mathrm{O}_{3}$ and $\mathrm{MgO}$ were sintered at $1900^{\circ} \mathrm{C}$ for $2-48 \mathrm{~h}$ under $0.9 \mathrm{MPa}$ nitrogen pressure. Microstructure, lattice oxygen content and thermal conductivity of the sintered specimens were evaluated. All specimens had a duplex microstructure composed of small matrix grains and elongated grains. Thermal conductivities of sintered bodies were remarkably increased with sintering time and reached a maximum value of about $120 \mathrm{~W} \cdot \mathrm{m}^{-1} \cdot \mathrm{K}^{-1}$. The lattice oxygen content of dense silicon nitride sintered body decreased with sintering time. The thermal conductivity increased with decreasing the lattice oxygen content. So far, it was reported that the thermal conductivity of $\mathrm{Si}_{3} \mathrm{~N}_{4}$ was affected by grain size and morphology, composition and thickness of grain boundary layer. It was revealed that thermal conductivity of sintered specimen was closely related to the oxygen content present in the silicon nitride lattice.
\end{abstract}

[Received August 15, 2001; Accepted September 26, 2001]

Key-words : Thermal conductivity, Lattice oxygen content, Silicon nitride, Ytterbium oxide, Magnesium oxide

\section{1. 緒言}

窒化ケイ素は高強度, 高勒性であり, その単結晶は $200 \mathrm{~W}$. $\mathrm{m}^{-1} \cdot \mathrm{K}^{-1}$ 以上の熱伝導率1,2)をもつと予測されている，それゆ え窒化ケイ素多結晶体は高い機械特性をもつ高熱伝導率材料と して期待されている3) 8)，熱伝導に影響を及ぼす外的な要因と して大きくは粒内欠陷と粒界ガラス相が挙げられる．窒化ケイ 素焼結体中の残留ガラス相は多粒子粒界にガラスポケットとて 存在するだけでなく，二粒子粒界に $1 \mathrm{~nm}$ 程度のガラスフィル ムとして存在することが知られている．Kitayama ら99 はこれ ら粒界ガラス相と熱伝導率との間の関係について検討を行い, 粒子径が $1 \mu \mathrm{m}$ 程度以上であれば粒界ガラス相の熱伝導率への 影響は小さいことを示した. $\mathrm{Si}_{3} \mathrm{~N}_{4}$ 粒子内部への固溶元素の影 響についてはいくつかの報告がなされている，Al，Oなどは $\mathrm{Si}_{3} \mathrm{~N}_{4}$ の粒子内に一部固溶し，フォノンの散乱を起こすため熱 伝導率を低下させるとされている(4),10) 12)。同じ窒化物である AlN の熱伝導率は Slack $^{13)}$ により系統的に調べられ，固溶酸素 量の関数として整理されている. Kitayamaらは種ヶの希土類 酸化物助剤を添加した $\mathrm{Si}_{3} \mathrm{~N}_{4}$ を作製し，焼結助剤の効果につい て固溶酸素量に注目して議論を行った ${ }^{14)}$ 。その結果, $\mathrm{Y}_{2} \mathrm{O}_{3}$ と $\mathrm{Yb}_{2} \mathrm{O}_{3}$ 添加は他の希土類酸化物を添加するよりも, 固溶酸素量 は少なく熱伝導率が高いことを明らかにした2)。彼らは出発原 料に $\alpha$ 型窒化ケイ素を用いていたホットプレス焼結を行っ た. 本研究では $\alpha-\beta$ 相転移の影響をなくし, 溶解再析出反心 による粒内純化に焦点を絞るため，またホットプレス焼結では 不純物が系外へ排出されにくいので開放系での焼結が最適であ ると考光， $\beta$ 型窒化ケイ素粉末を用いて常圧焼結を行った． $\mathrm{Yb}_{2} \mathrm{O}_{3}-\mathrm{MgO}$ を焼結助剤として焼結体を作製し，固溶酸素量に 注目して熱伝導率との因果関係を明らかにすることを目的とし た.

\section{2. 実験方法}

$\beta$ 型 $\mathrm{Si}_{3} \mathrm{~N}_{4}$ 粉末（純度 $99.9 \%$ 以上, BET $11.2 \mathrm{~m}^{2} / \mathrm{g}, \alpha$ 化率 $3.4 \%$; 電気化学工業製) に焼結助剤として $\mathrm{Yb}_{2} \mathrm{O}_{3}$ 粉末（純度 $99.9 \%$ 以上, $\mathrm{BET} 17.6 \mathrm{~m}^{2} / \mathrm{g}$ ；日本イットリウム製）と $\mathrm{MgO}$ 粉末(1000 A, 宇部興産製)を添加した. 組成はモル比で $\mathrm{Si}_{3} \mathrm{~N}_{4}$ : $\mathrm{Yb}_{2} \mathrm{O}_{3}: \mathrm{MgO}=93: 2: 5,92: 3: 5,91: 4: 5,90: 5: 5$ とな るようにした，混合粉末に 0.5 mass\%の分散剤を添加し（Reogard GP，ライオン化学製）メタノールを分散媒とし, 窒化ケ イ素のボールとポットを用いて遊星ミルで $1 \mathrm{~h}$ 混合した，ス ラリーはエバポレータを用いて $65^{\circ} \mathrm{C}$ 乾燥させ, 次に真空中 $100^{\circ} \mathrm{C} て ゙ 12 \mathrm{~h}$ 乾燥させた。得られた乾燥粉末を 60 メッシュのふ るいに通し， $\mathrm{N}_{2}$ 雲囲気中 $600^{\circ} \mathrm{C}, 2 \mathrm{~h}$ で仮焼した。仮焼粉末を $\phi 20 \times 5 \mathrm{~mm}$ の形状に一軸成形後 $(15 \mathrm{MPa})$, 更に500 MPa の 圧力で冷間静水圧プレス (CIP) 成形した。成形体は BN 粉末 を敷いた $\mathrm{BN}$ るつぼに入れてグラフォイト炉で $0.9 \mathrm{MPa}$ 窒素ガ 又压で $1900^{\circ} \mathrm{C}, 2 \sim 48 \mathrm{~h}$ で焼成した，得られた焼結体の相同定 はX線回折装置（RINT2500，理学製）を用いて行った。 た焼結体の密度はアルキメデス法により求めた。

焼結体を\#200の砥石で研削し, 直径 $10 \mathrm{~mm}$, 厚さ $2 \mathrm{~mm}$ に 加工した. 試料表面には金コート (厚さ $6 \mu \mathrm{m}$ ) 及びカーボン コートを施した、レーザーフラッシュ装置（TC-7000，真空 理工製）を用いて熱拡散率と比熱の測定を行い，熱伝導率 $k$ は 次式加求めた。

$$
k=\rho C_{\mathrm{p}} \alpha
$$

ここで， $\rho$ は密度， $C_{\mathrm{p}}$ は比熱， $\alpha$ は熱拡散率である。すべての 試料の比熱を測定した結果, 組成や焼成条件にかかわらず同様 な值を示したので，測定結果の平均值から $0.68 \mathrm{~J} \cdot \mathrm{g}^{-1} \cdot \mathrm{K}^{-1}$ を 用いた。

その後試料を二分割し，一方を微構造観察用，他方を酸素測 定用試料として用いた。試料を $1 \mu \mathrm{m}$ サイズのダイヤモンドス ラリーで鏡面研磨した後, $\mathrm{CF}_{4}$ ガスを用いてプラズマエッチン 
グを行い，走査型電子顕微鏡（SEM; JSM-6340F， 日本電子 製）を用いて微構造を観察した。

また，酸素測定用試料の表面をすべて研削してから粉砕し， 酸処理を行って粒界相を除去して固溶酸素量測定用の試料とし た ${ }^{15), 16)}$ 。酸素窒素分析装置 (TC-436, LECO, St Joseph, MI, USA）を用いてホットガス抽出法により分析を行った.

\section{3. 結果と考察}

図 1 に焼成時間に伴う各試料の密度の变化を示す. $2 \mathrm{~h}$ 焼結 体は原料混合時の理論密度とほぼ同じ值を示したが，その後は 焼成時間に伴って密度は減少し， $\beta-\mathrm{Si}_{3} \mathrm{~N}_{4}$ の理論密度に漸近す る傾向にあった。後でも述べるように SEM 観察では各試料は 気孔のない緻密な焼結体であることが確認できた。なお各試料 とも $2 \mathrm{~h}$ 焼結体は配合組成から計算した理論密度とほぼ同じ值 を示した. 重量減少率 (図 2 ) は焼成時間に伴って増加したが, 飽和する傾向にあった。これらのことから各試料は短時間で緻 密化し，それ以降においては助剤成分が蒸発したものと考えら れた。 そこでX 線回折測定により焼結体の相同定を行った。

X 線回折測定による相同定は焼結体の表面と500 $\mu \mathrm{m}$ 削った 内部でそれぞれ行った，表 1 には各試料について $2 \mathrm{~h}$ と $48 \mathrm{~h}$ の 結果をまとめて示す。試料表面においてはいずれの試料も焼成 時間の増加に伴って $\beta-\mathrm{Si}_{3} \mathrm{~N}_{4}$ 相が減少し, $\mathrm{Yb}_{4} \mathrm{Si}_{2} \mathrm{~N}_{2} \mathrm{O}_{7}$ 相が増 加した。特に $\mathrm{Yb}_{4} \mathrm{Si}_{2} \mathrm{~N}_{2} \mathrm{O}_{7}$ 相は $\mathrm{Yb}_{2} \mathrm{O}_{3}$ 添加量が増えるにつれ 増加していた． $2 \mathrm{~h}$ 焼成においては $\mathrm{Yb}_{2} \mathrm{Si}_{3} \mathrm{~N}_{2} \mathrm{O}_{5}$ 相の存在も認 められた. $48 \mathrm{~h}$ 焼成試料では $\mathrm{Yb}_{2} \mathrm{Si}_{3} \mathrm{~N}_{4} \mathrm{O}_{3}$ 相の存在が認めら れた。確認された酸窒化物の中で $\mathrm{Yb}_{2} \mathrm{Si}_{3} \mathrm{~N}_{2} \mathrm{O}_{5}, \mathrm{Yb}_{4} \mathrm{Si}_{2} \mathrm{~N}_{2} \mathrm{O}_{7}$, $\mathrm{Yb}_{2} \mathrm{Si}_{3} \mathrm{~N}_{4} \mathrm{O}_{3}$ の順に $\mathrm{SiO}_{2}$ 含有量が少なくなる. 特に $\mathrm{Yb}_{2} \mathrm{Si}_{3} \mathrm{~N}_{4} \mathrm{O}_{3}$ 相は $\mathrm{Si}_{3} \mathrm{~N}_{4}-\mathrm{Yb}_{2} \mathrm{O}_{3}$ 上に存在する相で $\mathrm{SiO}_{2}$ を含まない。以上の ことから, 試料表面においては焼成時間の増加とともに $\mathrm{Yb}-$ $\mathrm{Si}-\mathrm{N}-\mathrm{O}$ 系化合物が増加し, 更にこの酸窒化物の組成は $\mathrm{SiO}_{2}$ が揮発する17),18)ことにより窒素リッチなものに変化している ことがうかがえた。

一方, 試料内部は焼成時間に関係なく母相の $\beta-\mathrm{Si}_{3} \mathrm{~N}_{4}$ 相之 $\mathrm{Yb}_{4} \mathrm{Si}_{2} \mathrm{~N}_{2} \mathrm{O}_{7}$ 相が認められた. 短時間焼成では若干他の酸窒化

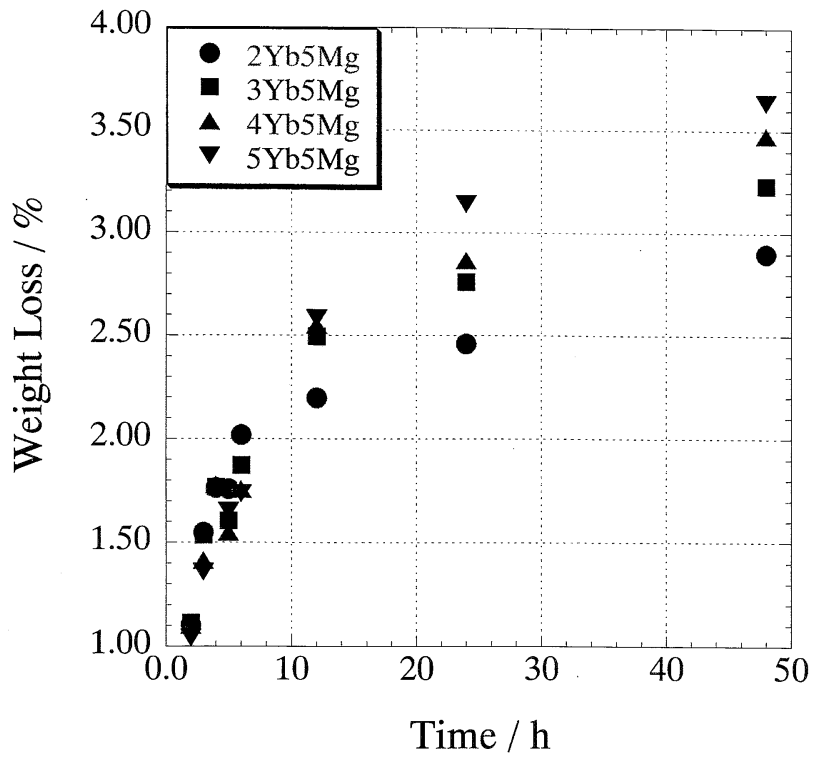

Fig. 2. Relationship between weight loss and sintering time of all specimens.

物の相も認められた。 また焼結助剂が多いほど $\mathrm{Yb}_{4} \mathrm{Si}_{2} \mathrm{~N}_{2} \mathrm{O}_{7}$ 相 の強度は大きくなり, 焼成時間とともに強度は小さくなった。 したがって Yb も表面に移動し, 試料内部から消失している傾 向がうかがえた. 更に第 2 相の相変化については次のように 考えられる. 本実験で用いた組成を図 393 成分系ダイヤグ ラム内に示す.な招 $\mathrm{SiO}_{2}$ は, $\mathrm{Si}_{3} \mathrm{~N}_{4}$ 原料粉末に含まれている 不純物酸素を $\mathrm{SiO}_{2}$ に換算して求めた. 本実験で用いた組成で は Yb 添加量が少なければ図中の II 相領域の化合物が，Yb 添 加量が多ければIII 相領域内の化合物がそれぞれ XRD で観察 されると考えられた．しかしながらすべての出発組成において 粒子内部では III 相領域内の $\mathrm{Yb}_{4} \mathrm{Si}_{2} \mathrm{~N}_{2} \mathrm{O}_{7}$ 化合物が認められ た.これは試料表面の XRD 結果からも分かるように $\mathrm{SiO}_{2}$ が

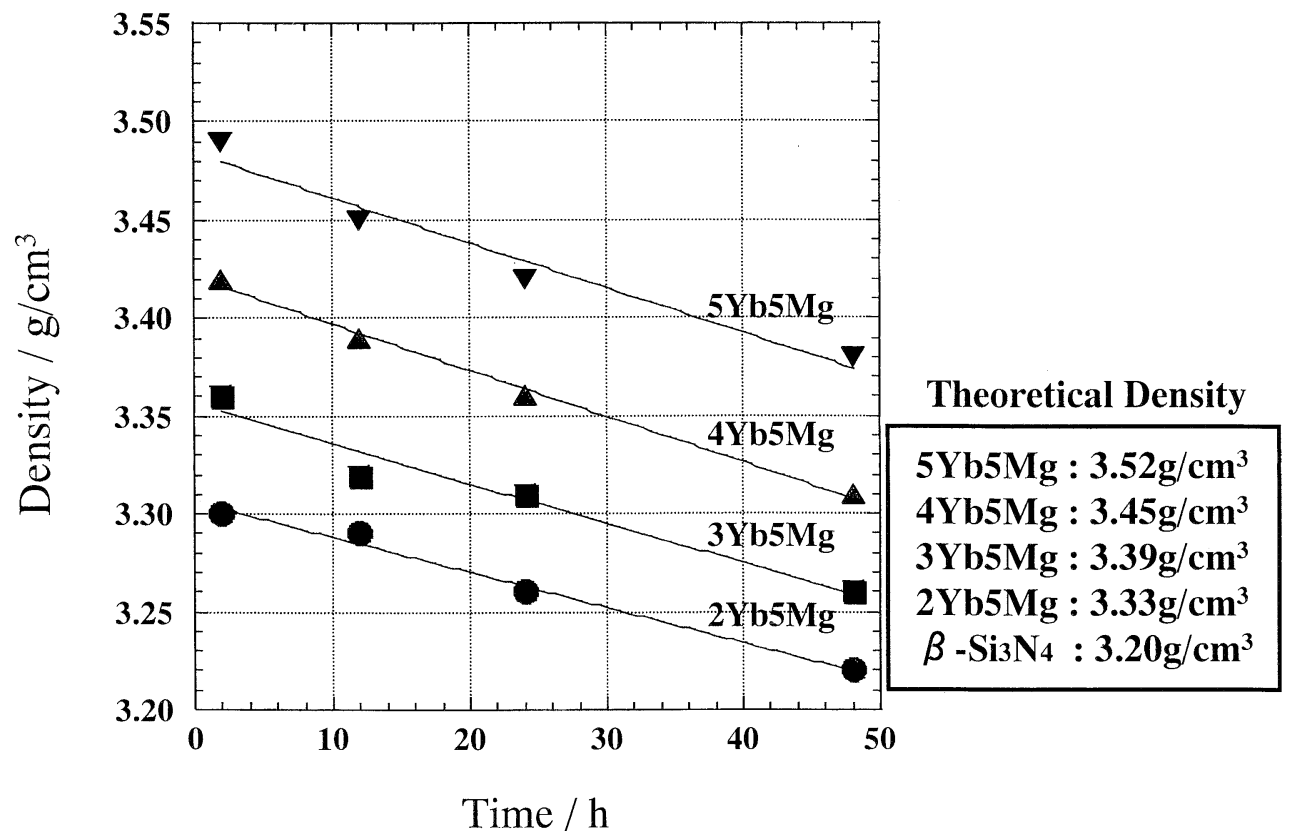

Fig. 1. Bulk densities and theoretical densities of all specimens. 
Table 1. XRD Phase Identification Result

\begin{tabular}{|c|c|c|c|c|c|c|}
\hline Sample Name & Sintering Time & Position & $\beta-\mathrm{Si}_{3} \mathrm{~N}_{4}$ & $\mathrm{Yb}_{4} \mathrm{Si}_{2} \mathrm{~N}_{2} \mathrm{O}_{7}$ & $\mathrm{Yb}_{2} \mathrm{Si}_{3} \mathrm{~N}_{2} \mathrm{O}_{5}$ & $\mathrm{Yb}_{2} \mathrm{Si}_{3} \mathrm{~N}_{4} \mathrm{O}_{3}$ \\
\hline \multirow[t]{4}{*}{$2 \mathrm{Yb}_{2} \mathrm{O}_{3}+5 \mathrm{MgO}$} & $2 \mathrm{~h}$ & surface & very strong & strong & weak & - \\
\hline & & inner & very strong & very strong & - & - \\
\hline & $48 \mathrm{~h}$ & surface & weak & strong & - & - \\
\hline & & inner & very strong & weak & - & - \\
\hline \multirow[t]{4}{*}{$3 \mathrm{Yb}_{2} \mathrm{O}_{3}+5 \mathrm{MgO}$} & $2 \mathrm{~h}$ & surface & very strong & strong & weak & - \\
\hline & & inner & very strong & very strong & - & - \\
\hline & $48 \mathrm{~h}$ & surface & weak & strong & - & - \\
\hline & & inner & very strong & - & - & - \\
\hline \multirow[t]{4}{*}{$4 \mathrm{Yb}_{2} \mathrm{O}_{3}+5 \mathrm{MgO}$} & $2 \mathrm{~h}$ & surface & very strong & strong & strong & - \\
\hline & & inner & very strong & very strong & - & - \\
\hline & $48 \mathrm{~h}$ & surface & weak & very strong & - & - \\
\hline & & inner & very strong & weak & - & - \\
\hline \multirow[t]{4}{*}{$5 \mathrm{Yb}_{2} \mathrm{O}_{3}+5 \mathrm{MgO}$} & $2 \mathrm{~h}$ & surface & very strong & very strong & very strong & - \\
\hline & & inner & very strong & strong & - & - \\
\hline & $48 \mathrm{~h}$ & surface & weak & very strong & - & strong \\
\hline & & inner & very strong & weak & - & - \\
\hline
\end{tabular}
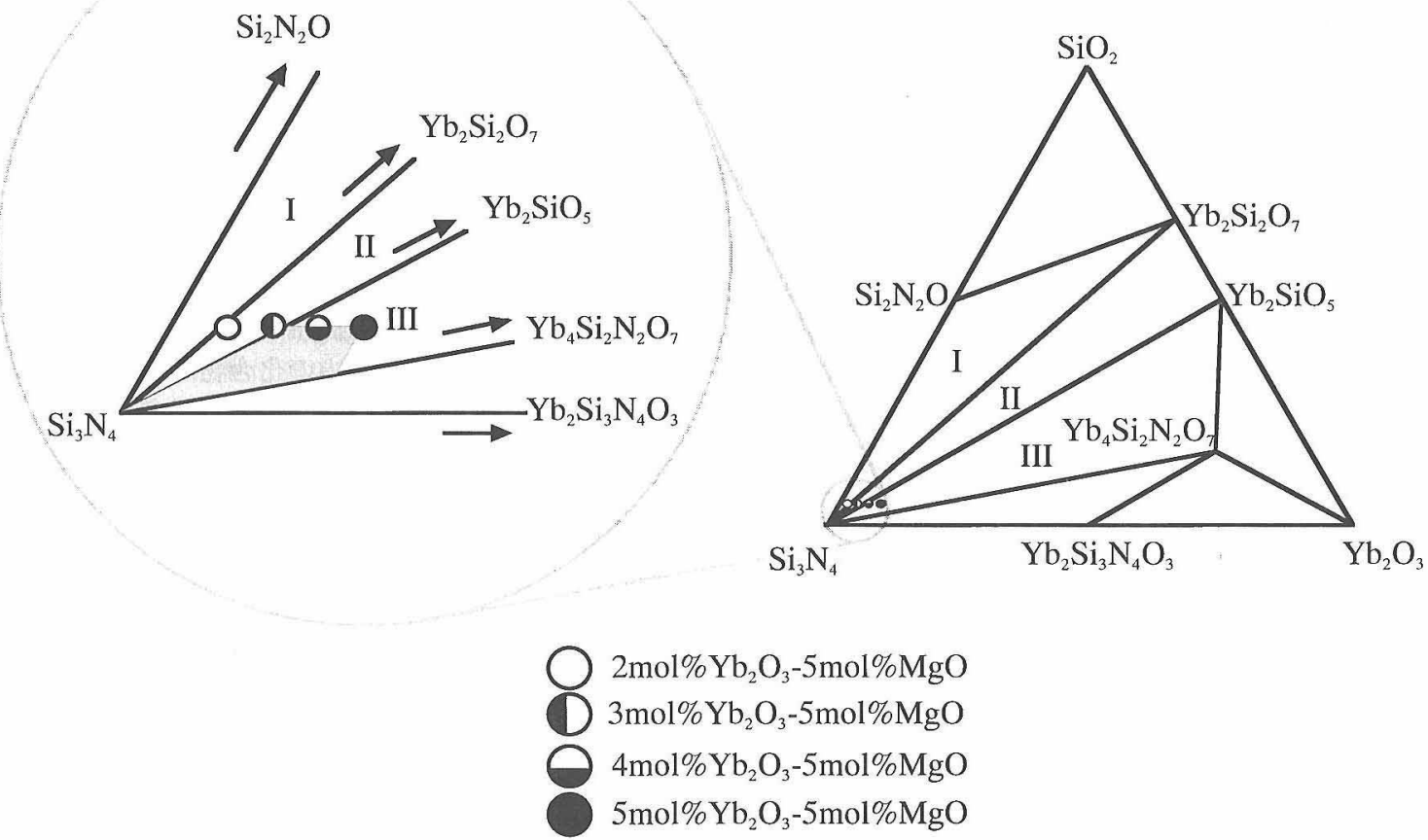

Fig. 3. Composition of this work's specimens in the ternary system of $\mathrm{Si}_{3} \mathrm{~N}_{4}-\mathrm{SiO}_{2}-\mathrm{Yb}_{2} \mathrm{O}_{3}$.

揮発し，3成分系での組成が III 相領域内に変化したためと考 えられる。

以上の X 線の結果と状態図の考察から $\mathrm{Yb}, \mathrm{Si}, \mathrm{O}$ 成分が蒸気 圧の高い化合物を形成して液相から蒸発し，第 2 相が組成変 動を起こしていることが分かった。 $\mathrm{Mg}$ に関しては結晶相とし て同定されず，ガラスを構成する成分として存在していると思 われるが，暁成温度が $1900^{\circ} \mathrm{C}$ と高く， $\mathrm{MgO}$ の蒸気圧が高いの で $\mathrm{MgO}$ むかなり揮発していると考えられる．定量的な結果を 得るには詳細な元素分析が必要である。

$2 \mathrm{~mol} \% \mathrm{Yb}_{2} \mathrm{O}_{3}$ 添加の試料の SEM 写真を図 4 に示す。すべ ての試料に招いて気孔はほとんど見当たらなかったことから緻
密な焼結体であるといえる。いずれの条件でも焼結体は微細な マトリックス粒子と大きく成長した柱状粒子からなる複合的な 微構造を示した，暁成時間の増加に伴い溶解再析出反応が進 み，粗大粒子は選択的に成長する傾向にあった，組成による組 織の大きな差異は認められなかった。

熱拡散率と熱伝導率の結果を表 2 に示す。熱拡散率々熱伝導 率はいずれの組成に抢いても焼成時間の増加に伴い高くなっ た。熱伝導率は最大で $120 \mathrm{~W} \cdot \mathrm{m}^{-1} \cdot \mathrm{K}^{-1}$ を示した，熱伝導率は 比熱々密度と熱拡散率の積で求められるため密度の影響も受け る、密度は組成によって異なり $\mathrm{Yb}_{2} \mathrm{O}_{3}$ 添加量が大きいほよ゙密 度は大きい。この密度の差で見掛け上熱伝導率は組成の影響を 

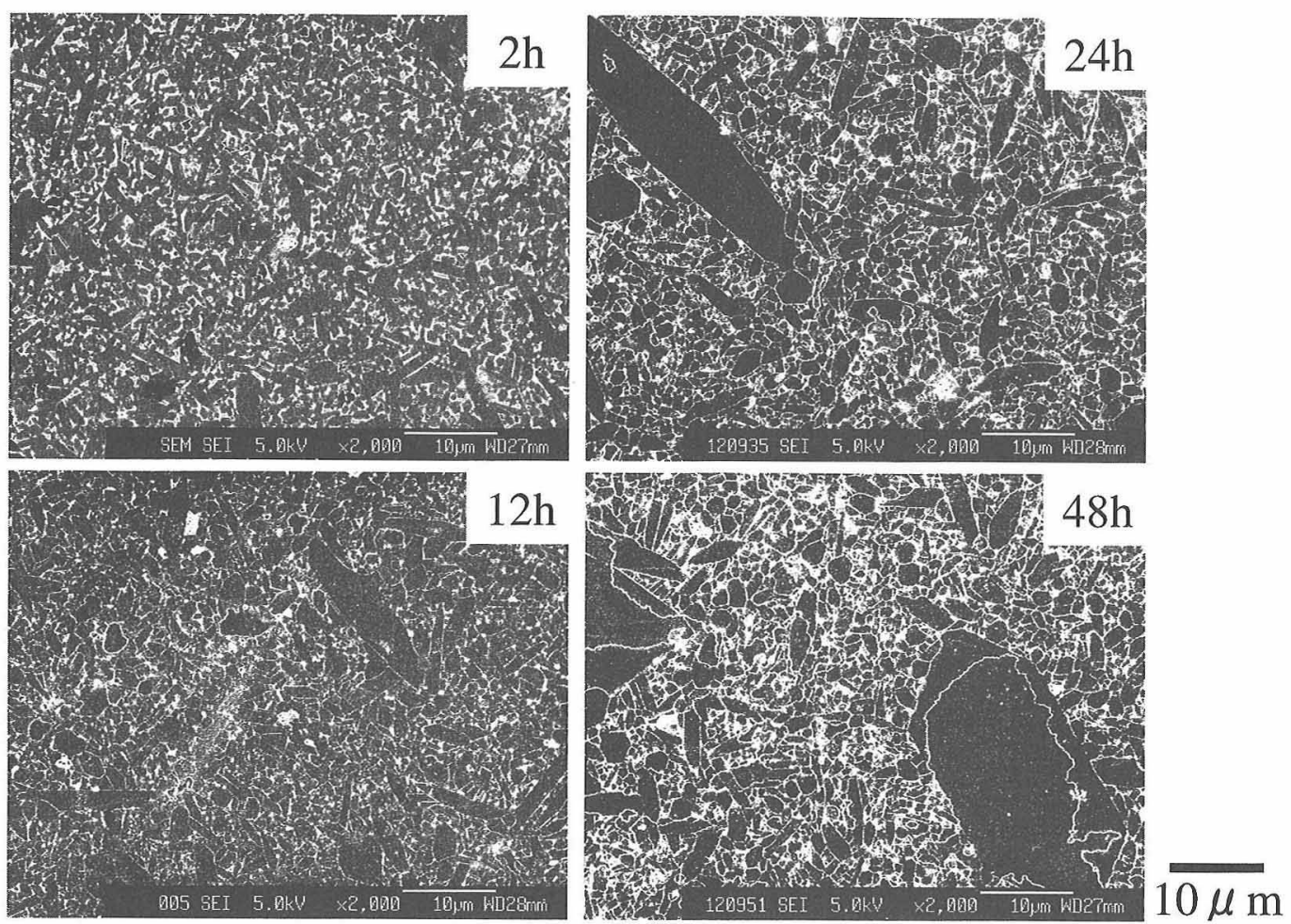

Fig. 4. SEM photographs of polished and plasma-etched surface of sintered specimens: (a) $2 \mathrm{~h}$, (b) $12 \mathrm{~h}$, (c) $24 \mathrm{~h}$ and (d) $48 \mathrm{~h}$.

Table 2. Density, Thermal Diffusivity and Thermal Conductivity for All Specimens

Sample Name Sintering Time (h) Density $\left(\mathrm{g} / \mathrm{cm}^{3}\right)$ Thermal Diffusivity $\left(\mathrm{cm}^{2} / \mathrm{s}\right)$ Thermal Conductivity (W/mK)

\begin{tabular}{ccccc}
\hline $2 \mathrm{Yb}_{2} \mathrm{O}_{3}+5 \mathrm{MgO}$ & 2 & 3.30 & 0.39 & 88 \\
& 12 & 3.29 & 0.43 & 96 \\
& 24 & 3.26 & 0.50 & 112 \\
& 48 & 3.22 & 0.54 & 88 \\
\hline $3 \mathrm{Yb}_{2} \mathrm{O}_{3}+5 \mathrm{MgO}$ & 2 & 3.36 & 0.38 & 101 \\
& 12 & 3.32 & 0.45 & 114 \\
& 24 & 3.31 & 0.51 & 121 \\
\hline $4 \mathrm{Yb}_{2} \mathrm{O}_{3}+5 \mathrm{MgO}$ & 48 & 3.26 & 0.55 & 92 \\
& 2 & 3.42 & 0.40 & 104 \\
& 12 & 3.39 & 0.45 & 117 \\
& 24 & 3.36 & 0.51 & 119 \\
\hline $5 \mathrm{Yb}_{2} \mathrm{O}_{3}+5 \mathrm{MgO}$ & 48 & 3.31 & 0.53 & 93 \\
& 2 & 3.49 & 0.39 & 106 \\
& 12 & 3.45 & 0.45 & 120 \\
& 24 & 3.42 & 0.52 & 122 \\
\hline
\end{tabular}

受けているように見えるが，熱拡散率で比較した場合には組成 による差は認められなかった。

固溶酸素量の測定には，熱定数測定に用いたサンプルの表面 を削った後粉砕し，酸処理を行って粒界相を除去したものを用 いた，当研究室でこれまでに確立された分析方法9) 12),19)で固 溶酸素量を算出した。 その結果を図 5 に示す。出発原料 $\beta$ $\mathrm{Si}_{3} \mathrm{~N}_{4}$ 中のトータル酸素量は 0.78 mass \% で固溶酸素量は 0.48 mass\%であった。焼成時間に伴って固溶酸素量は低下した。 試料の焼成に当たっては開放系の中で行われているため, 不純 物 $\mathrm{Si}$ をはし゚め助剂成分で形成される化合物が蒸発しやすい環 境になっている. 溶解再析出反応により粒内の酸素が低減し, 重量減少やX 線回折測定の結果からも分かると招り助剤成分
及び不純物 $\mathrm{SiO}_{2}$ は液相から蒸気压の高い化合物を形成して系 外に放出されている. そのため熱伝導率も固溶酸素量もホット プレス焼結で作製した試料より良好な結果が得られたと考えら れる.

$\mathrm{Slack}^{13)}$ は AlN 単結晶について不純物酸素量と熱伝導率の関 係を系統的に調べ，AlN 中の酸素含有濃度と熱抵抗率（熱伝 導率の逆数）がほぼ直線的な関係にあることを示した. 図 6 に は本実験で得られた焼結体中の固溶酸素量と熱抵抗率の関係を 示した. なた図中には Kitayama らの実験結果も示した. 固溶 酸素量が低下すると熱抵抗率がほほ直線的に減少した。 Kitayama らの試料はホットプレス焼結で作製され, 出発原料は $\alpha$ $\mathrm{Si}_{3} \mathrm{~N}_{4}, \mathrm{Y}_{2} \mathrm{O}_{3}$ と異なる.しかしながら今回の実験では Kitayama 


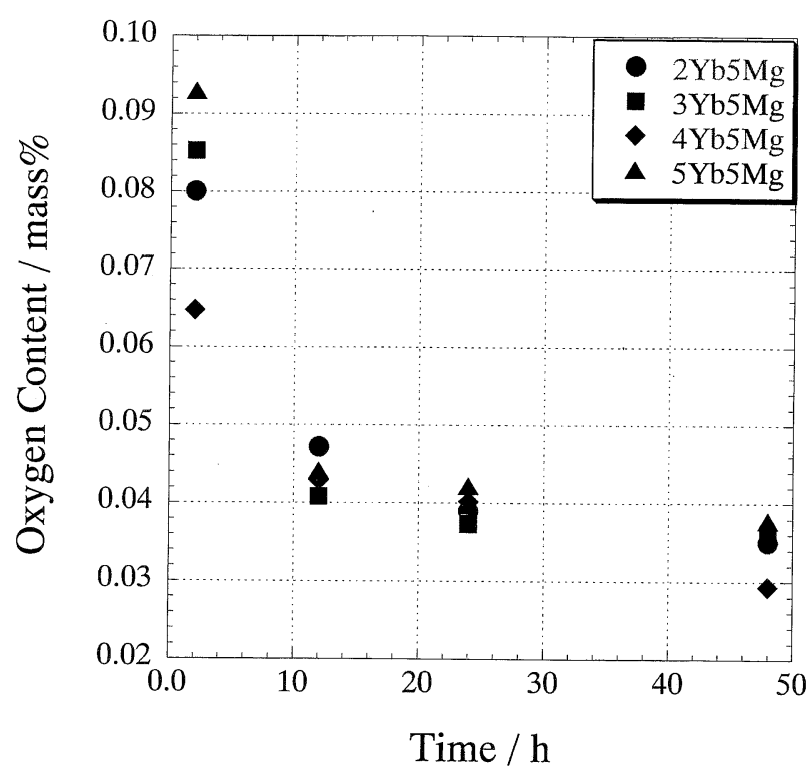

Fig. 5. Relationship between lattice oxygen contents and sintering time of all specimens.

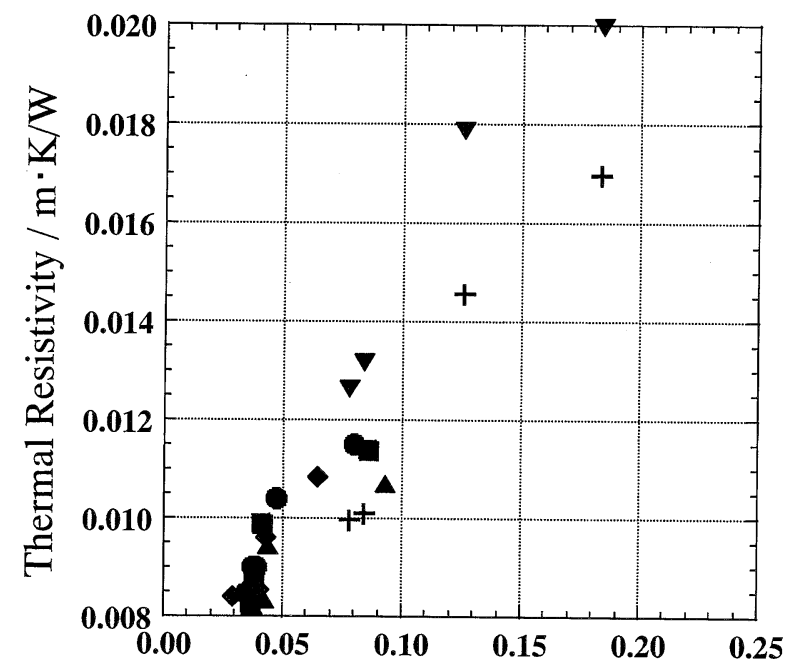

Oxygen Content / mass $\%$

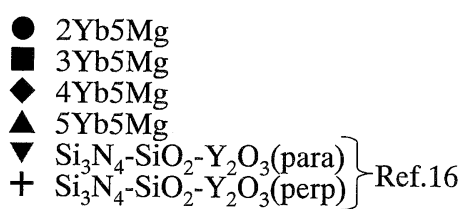

Fig. 6. Relationship between lattice oxygen contents and thermal resistivities of $2 \mathrm{~mol} \% \mathrm{Yb}_{2} \mathrm{O}_{3}-5 \mathrm{~mol} \% \mathrm{MgO}$ doped $\mathrm{Si}_{3} \mathrm{~N}_{4}$ and the data of the previous work (Ref. 16).

らの結果と同様の傾向を示しかつデータに連続性が見られた. したがって熱伝導率は粒内不純物である固溶酸素に大きく支配
されていることが確認された。また，グラフより固溶酸素量を 0 mass\%に外挿すると熱伝導率は $180 \sim 190 \mathrm{~W} \cdot \mathrm{m}^{-1} \cdot \mathrm{K}^{-1}$ に至 ることが予想された。

\section{4. 結 論}

$\mathrm{Yb}_{2} \mathrm{O}_{3}-\mathrm{MgO}$ 添加 $\mathrm{Si}_{3} \mathrm{~N}_{4}$ 焼結体の熱伝導率に及ぼす酸素の影 響について検討を行った. 常圧焼結で最大 $120 \mathrm{~W} \cdot \mathrm{m}^{-1} \cdot \mathrm{K}^{-1}$ を 示す焼結体を作製することに成功した．多くの試料で，小さな 粒子と巨大な粒子とからなる複合構造が見られた．焼成時間の 増加に伴い熱伝導率は向上し, 固溶酸素量は低下した。作製方 法や平均粒径の異なる $\mathrm{Si}_{3} \mathrm{~N}_{4}$ 焼結体の熱伝導率を比較したが, すべて粒子内の酸素量で整理することができ, 粒子内の純化す なわち固溶酸素の存在が $\mathrm{Si}_{3} \mathrm{~N}_{4}$ の熱伝導率に大きく影響を及ぼ していることを示している.

謝辞本研究は経済産業省産業技術環境局が推進する産業 技術基盤研究開発プロジェクト「シナジーセラミックスの研究開 発」の一環として, シナジーセラミックス研究体に所属する著者 らによって行われたものである. $\beta$ 型窒化ケイ素粉末を提供して いただいた電気化学工業株式会社に感謝の意を表しすす。

\section{文献}

1) Haggerty, J. S. and Lightfoot, A., Ceram. Eng. Sci. Proc., 16, 475-87 (1995).

2) Watari, K., J. Ceram. Soc. Japan, 109, S7-16 (2001).

3) Hirao, K., Watari, K., Brito, M. E., Toriyama, M. and Kanzaki, S., J. Am. Ceram. Soc., 79, 2485-88 (1996).

4) Hirosaki, N., Okamoto, Y., Ando, M., Munakata, F. and Akimune, Y., J. Ceram. Soc. Japan, 104, 49-53 (1996) [in Japanese].

5) Hirosaki, N., Ando, M., Okamoto, Y., Munakata, F., Akimune, Y., Hirao, K., Watari, K., Brito, M. E., Toriyama, M. and Kanzaki, S., J. Ceram. Soc. Japan, 104, 1171-73 (1996) [in Japanese].

6) Akimune, Y., Munakata, F., Matsuo, K., Hirosaki, N., Okamoto, Y. and Misono, K., J. Ceram. Soc. Japan, 107, 339-42 (1999) [in Japanese].

7) Watari, K., Hirao, K., Brito, M. E., Toriyama, M. and Kanzaki, S., J. Mater. Res., 14, 1538-41 (1999).

8) Akimune, Y., Munakata, F., Matsuo, K., Okamoto, Y., Hirosaki, N. and Satoh, C., J. Ceram. Soc. Japan, 107, 1180-82 (1999) [in Japanese].

9) Kitayama, M., Hirao, K., Toriyama, M. and Kanzaki, S., J. Am. Ceram. Soc., 82, 3105-12 (1999).

10) Watari, K., Seki, Y. and Ishizaki, K., J. Ceram. Soc. Japan, 97, 56-62 (1989) [in Japanese].

11) Hirosaki, N., Okamoto, Y., Ando, M., Munakata, F. and Akimune, Y., J. Am. Ceram. Soc., 79, 2878-82 (1996).

12) Watari, K., Hirao, K., Toriyama, M. and Ishizaki, K., J. Am Ceram. Soc., 82, 777-79 (1999).

13) Slack, G. A., J. Phys. Chem. Solids, 34, 321-35 (1973).

14) Kitayama, M., Hirao, K., Watari, K., Toriyama, M. and Kanzaki, S., J. Am. Ceram. Soc., 84, 353-58 (2001).

15) Kitayama, M., Hirao, K., Tsuge, A., Toriyama, M. and Kanzaki, S., J. Am. Ceram. Soc., 82, 3263-65 (1999).

16) Kitayama, M., Hirao, K., Tsuge, A., Watari, K., Toriyama, M. and Kanzaki, S., J. Am. Ceram. Soc., 83, 1985-92 (2000).

17) Yokoyama, K. and Wada, S., J. Ceram. Soc. Japan, 108, 230-35 (2000).

18) Yokoyama, K. and Wada, S., J. Ceram. Soc. Japan, 108, 357-64 (2000).

19) Hayashi, H., Hirao, K., Toriyama, M., Kanzaki, S. and Itatani, K., accepted to J. Am. Ceram. Soc. 